\title{
Water and Agriculture in a Changing Climate
}

\author{
Michael P. O'Neill ${ }^{1}$ and James P. Dobrowolski \\ USDA National Institute of Food \& Agriculture, 800 9th Street SW, Washington, DC 20250-2210
}

Additional index words. global change, water resources, agricultural water security

\begin{abstract}
Agriculture, in its broadest form, is the greatest consumptive user of water resources in the United States and around the world. Perhaps the greatest challenge facing agricultural producers will be adapting water management to an increasingly variable climate. Adaptation will be extremely difficult, in part because other demands for water (e.g., energy, domestic, industrial, municipal) will continue to increase. Despite considerable improvements in irrigation technology, product development, and other water-saving approaches, agricultural producers will be expected to reduce water consumption and improve or protect water quality of water discharged from agricultural operations. In 2004, the National Institute of Food and Agriculture embarked on an effort to address Agricultural Water Security, ensuring sufficient water of the appropriate quality at the needed time to meet demands for food, fiber, and other agricultural goods and services. This effort identified six broad areas where agricultural research, education, and extension can impact water management to achieve agricultural water security. The six areas are: biotechnology, water reuse, general conservation, irrigation efficiency, water markets and trading, and drought preparedness. We present an overview of the six areas and opportunities for agriculture-and specifically horticultural and specialty crop producers - to adapt to climate change through improved water management.
\end{abstract}

Since 1990, considerable effort has been expended to characterize the impact of human activities on global climate [Intergovernmental Panel on Climate Change (IPCC), 2001; IPCC, 2007; Karl et al., 2009]. Potential impacts of global change include an increase in temperature; changes in atmospheric composition, including $\mathrm{CO}_{2}, \mathrm{~N}_{2} \mathrm{O}$, methane, and other trace gases; changes in the timing, frequency, duration, and type of precipitation; rising sea level; and many other responses (IPCC, 2001; IPCC, 2007, Karl et al., 2009). A great deal of scientific research has addressed the observed rise in mean global temperature and the potential anthropogenic causes of that temperature rise (IPCC, 2001, 2007). By contrast, far less is known about the impacts of the changing climate on water resources (IPCC, 2007; Karl et al., 2009; Knutson, 2008; Lins et al., 2010; Vorosmarty et al., 2000, 2010). Current global change models have considerable uncertainty regarding future precipitation patterns (Liang et al., 2008). Much of this uncertainty is linked to the inability of current global change models to "downscale" hydrologic model predictions from continental to regional or local scales (Wilby and Wigley, 1997). Moreover, current hydrologic "trends" in precipitation and runoff also lack stationarity, indicating that traditional predictive models and tools are not appropriate for predicting future precipitation or runoff(Milly et al., 2008). Finally, predicted changes in precipitation and runoff show considerable spatial variability across the United States (Fig. 1).

Since the 1940s, agriculture (we use the term agriculture to represent the broadest interpretation of food, feed, fiber, and other goods and services) has enjoyed a period of

Received for publication 10 Sept. 2010. Accepted for publication 2 Nov. 2010.

This paper was part of the colloquium "Water Management and Plant Performance in a Changing Climate" held 4 Aug. 2010 at the ASHS Conference, Palm Desert, CA, and sponsored by the Water Utilization and Plant Performance in a Changing Climate (WUM) Working Group.

${ }^{1}$ To whom reprint requests should be addressed; e-mailmoneill@nifa.usda.gov. unparalleled growth in production (Wiebe, 2003). Much of this expanded production has come through improved genetic varieties, improved management, and extensive use of agricultural inputs, namely, water and commercial fertilizer. Current estimates of consumptive water use show that agriculture accounts for $70 \%$ to $80 \%$ of the total consumptive water use on a global scale. In the United States, the USGS' most recent 5-year survey of water withdrawals by sector and state show that thermoelectric power generation and irrigation account for the greatest water withdrawals (see Fig. 2; Barber, 2009; Kenny et al., 2009). Agriculture, including crop production, livestock, and aquaculture, accounts for $\approx 34 \%$ of total withdrawals.

Since 1950, global population has steadily increased leading to growing demand for water among all sectors: agricultural, domestic, municipal, energy, industrial, and environmental [Council for Agricultural Science and Technology (CAST), 2009]. Across much of the United States and in many regions around the globe, the response to the growing demand for domestic water supplies has been to limit traditional water uses such as agriculture (CAST, 2009). At the same time, new water demands are arising for in-stream flows to protect aquatic species and habitat further stressing already limited water supplies.

Not surprisingly, the growth in population since 1950 is mirrored by a growing demand for agricultural goods and services. Guidelines for healthy diets now stress increased consumption of fruits and vegetables (U.S. Department of Agriculture, 2005; see http:// www.MyPyramid.gov). Meeting consumers' expectations for healthier foods in the United States will require increased production of fruits and vegetables or increased imports of these food crops.

Climate uncertainty, shifting demands for limited water resources, and growing demand for agricultural goods and services create a "perfect storm" for agricultural water management. Now, more than ever, agricultural water managers and producers are being called on to reduce consumptive water use and expand production. However, it is not clear that the necessary management tools, markets, incentives, and practices exist to meet these new demands.

We believe that this perfect storm signals a need for a new paradigm for agricultural water management in which the focus is on water use efficiency leading to overall water conservation at the watershed scale. In this article, we outline the principles of a new paradigm for Agricultural Water Security to meet the challenges faced by agricultural producers and water managers.

\section{AGRICULTURAL WATER SECURITY}

In Sept. 2004, the U.S. Department of Agriculture (USDA) Research, Education, and Economics mission area hosted a listening session aimed at identifying strengths, knowledge gaps, challenges, and opportunities for a USDA response to agricultural water security issues (Dobrowolski and O'Neill, 2005). This listening session brought together potential partners and stakeholders to help define the future of the National Institute of Food and Agriculture's (NIFA) research, education, and extension funding programs for water resource management. Six broad areas were identified for USDA research, education, and extension programs to address agricultural water security: 1) water marketing, economics, and distribution; 2) water reuse; 3 ) general water conservation; 4) irrigation efficiency; 5) drought risk assessment; and 6) biotechnology. Participants in this listening session identified bold steps for the USDA to take within these six intervention areas that would help achieve a sustainable water scenario through the Year 2025. Participants in the listening session also identified appropriate federal, state, and local partners that must be engaged in these bold steps to ensure success.

The NIFA established an Agricultural Water Security Initiative that supports and coordinates research, education, and extension programs across the country to avoid crisis and conflict over agricultural water use. This Initiative brings together cutting-edge research and innovative education and outreach/extension to 


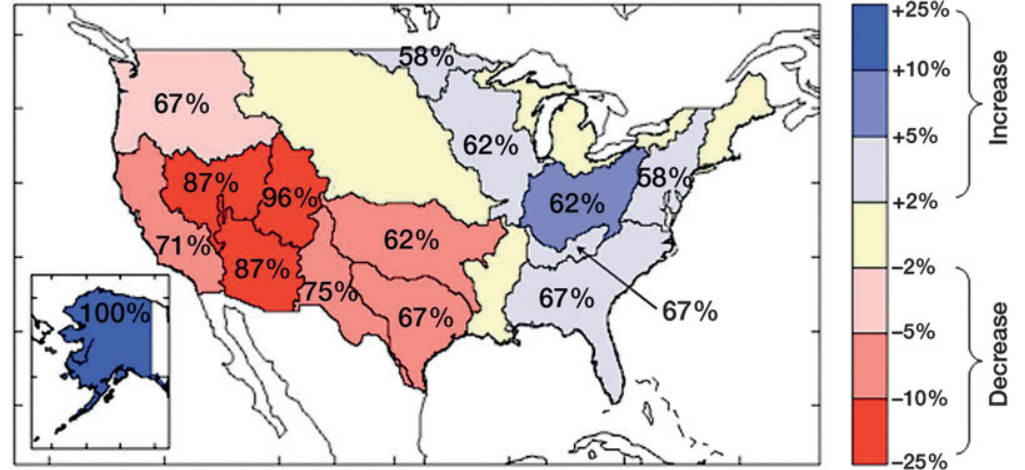

Fig. 1. Changes in runoff predicted from global climate models (from Climate Change Science Program, 2008). For the United States, decreases in median runoff (shown in red) dominate the Southwest, whereas increases (blue) are projected for parts of the midwest and eastern United States. Numbers in each region represent the percentage of simulations with similar sign (positive or negative). Data for Hawaii are not available.

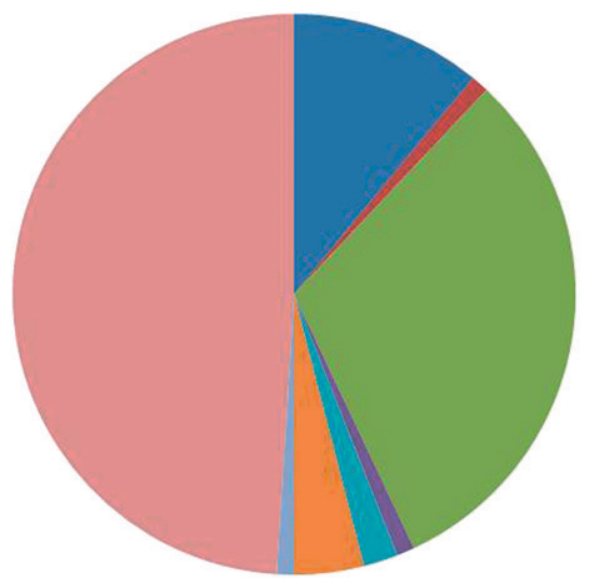

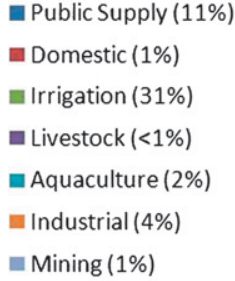

- Thermoelectric Power (49\%)

Fig. 2. U.S. water withdrawals by category in percentages. Figures do not differentiate between consumptive use and non-consumptive use (after Kenny et al., 2009).

focus on critical gaps in addressing the water supply, availability, distribution, and use. These gaps involve improving irrigation efficiency, developing new markets and water management tools, focusing on drought preparedness, developing and implementing rural/urban water reuse technologies and gaining adoption of these technologies, extending agricultural water conservation strategies to the urban sector, and developing water-relevant biotechnologies (Dobrowolski and O'Neill, 2005; see http:// www.csrees.usda.gov/nea/nre/in_focus/water_ if_security.html).

The following concepts define the NIFA Agricultural Water Security Initiative:

1. We need to better understand the future of irrigated agriculture in the Nation, including alternatives to irrigated agriculture for a safe, dependable food supply and determining how future climate change and population growth scenarios could affect water supplies and water demands. How will our Nation's agricultural industry respond to increasing competition from other countries?

2. We need to develop new science and technology focused on widening the array of choices for conserving water at the watershed scale. This new science should evaluate how knowledge, incentives, and policies help to promote appropriate decision-making. We must develop tools, technologies, markets, and practices that promote increased agricultural production while decreasing consumptive water use by agriculture. Ultimately, we need to find ways to help agricultural water districts identify and cope with change such as urbanization and competition for water.

3. We need to extend and expand current paradigms for water education and extension/outreach. How can education play a role to cultivate effective water management and water policy from the individual to the community and the global level? This new paradigm should explore new strategies to understand behavioral change and how social and economic factors affect decision-making for water resources management.

\section{OPPORTUNITIES IN SPECIALTY AND HORTICULTURAL CROPS}

Agricultural water security represents a considerable challenge to the agricultural sector, but it also offers great opportunities to develop a fundamental shift in how the USDA addresses water resource management. Now, more than ever, we must seek "holistic" solutions to water management issues in which agricultural water use is evaluated in the context of energy, environment, community, and other water uses.

The NIFA is focused on three themes that appear to offer the greatest promise for nearterm gains in agricultural water security:

1. Exploring new technologies and systems for the use of recycled/reuse water in agricultural, rural, and urbanizing watersheds;

2. Identifying "drought triggers"- threshold values of drought indicators that tie the levels of drought severity with appropriate responses to maintain agricultural production; and

3. Discovering biotechnological improvements in water use efficiency of crop and horticultural plants to achieve greater "crop per drop."

These three themes from the participantled agricultural water security listening session fit within the research and education challenges (water availability, quantity and quality; water use; and water institutions) described by the National Research Council (2001, 2004) and supported by the Administration (National Science and Technology Council Committee on Environment and Natural Resources Subcommittee on Water Availability and Quality, 2007). Several NIFA funding programs currently support elements of these challenges (Table 1).

Use of recycled wastewater in agriculture offers an excellent opportunity to supplement current surface and groundwater supplies used for irrigation of specialty and horticultural crops. However, the nearly uniform supply of wastewater throughout the year does not match typical irrigation demands. New strategies are needed to match supply and demand through storage or other mechanisms (Dobrowolski et al., 2008). When food crops are involved, the advantages of constructing storage ponds must be weighed against the potential risk of pathogens entering the water supply from wildlife using these ponds. Where recycled water is redirected to agriculture - upstream or in an adjacent watershed - there can be potentially damaging impacts downstream of the treatment plant. Water reuse likely will decrease flows downstream from wastewater facilities. It is also possible that localized increases to in-stream flows could occur where return flow from recycled wastewaster applied to specialty or horticultural crops enters streams. Finally, we face a considerable challenge overcoming public perception of the use of recycled water for food crops. Extension and outreach programs are needed to demonstrate the safety and environmental value of recycled water use.

Drought in the United States can easily exceed a billion dollar impact on the economy. Current programs to address drought focus primarily on mitigation of the impacts 


\begin{tabular}{|c|c|c|c|}
\hline Funding authority & Project types & Project focus area(s) & $\begin{array}{c}\text { Total funding } \\
\text { (Fiscal Year 2010) }\end{array}$ \\
\hline $\begin{array}{l}\text { Agriculture and Food Research Initiative } \\
\text { (AFRI)-Climate Change Challenge Area }\end{array}$ & $\begin{array}{l}\text { Regional Coordinated Agricultural } \\
\text { Projects } \\
\text { Integrated Projects }\end{array}$ & $\begin{array}{l}\text { Determining agriculture's water } \\
\text { and nitrogen "footprint" }\end{array}$ & $\$ 50$ million \\
\hline $\begin{array}{l}\text { Agriculture and Food Research Initiative } \\
\text { (AFRI)-Agricultural Water Science Program }\end{array}$ & Research Projects ${ }^{\mathrm{x}}$ & $\begin{array}{l}\text { Identifying drought triggers, use } \\
\text { of recycled water in agriculture }\end{array}$ & $\$ 4.5$ million \\
\hline Specialty Crops Research Initiative (SCRI) & $\begin{array}{l}\text { Coordinated Agricultural Projects } \\
\text { Integrated Projects }\end{array}$ & $\begin{array}{l}\text { Environmental implications of } \\
\text { specialty crop production }\end{array}$ & $\$ 47$ million \\
\hline $\begin{array}{l}\text { National Integrated Water Quality Program } \\
\text { (NIWQP) }\end{array}$ & $\begin{array}{l}\text { Integrated Watershed-Scale } \\
\text { Projects }\end{array}$ & $\begin{array}{c}\text { Water quality and availability } \\
\text { issues in rural, agricultural, } \\
\text { and urbanizing watersheds }\end{array}$ & $\$ 12$ million \\
\hline
\end{tabular}

${ }^{\mathrm{z}}$ Coordinated Agricultural Projects: typically, multistate, multi-institutional, multifunctional (research, education, and extension) projects.

yntegrated Projects: projects must include at least two functions (research, education, and/or extension).

${ }^{x}$ Research Projects: basic or applied research only.

For more information, visit http://www.nifa.usda.gov/fo/recentReleasedGrants.cfm.

of drought, after it occurs. We propose a shift to drought preparedness in which agricultural producers and communities have the necessary tools and management practices to plan for and recognize drought before it impacts agricultural production. The NIFA is interested in new research on drought triggers that warn of the potential for severe drought. With appropriate tools to identify the onset of severe drought, it could be possible that production of some fruits, vegetables, and container nursery plants could shift to species with lower water needs or higher value crops. However, tree crops (fruits, nuts, and landscape plants) are likely to require more dramatic shifts in management practices in preparation for anticipated severe droughts.

Considerable opportunity exists to use biotechnology to improve productivity or heartiness of specialty and horticultural crops where water availability is limited. Development of salt- and drought-tolerant species can take advantage of lesser water availability or use of lower quality water for irrigation. The NIFA is interested in research that demonstrates a shift in overall plant response, not just an increase in yield for a given water application rate. Attention also must be focused on product quality and not simply yield. Finally, advanced irrigation management practices will need to be developed to meet production goals while using less or lower quality irrigation water.

The NIFA is promoting integrative solutions for these three focal areas. We anticipate solutions that jointly address physical, biological, and social/economic sciences, the three pillars of sustainability. At the same time, we anticipate and recognize a need for functional integration of research, education, and extension. This functional integration poses a considerable opportunity for extension-led integrated projects that focus on timely solutions to stakeholder problems.

\section{SUMMARY}

Agricultural water management must respond to climate uncertainty, increasing demands from urban and suburban communities for limited water resources, and growing demand for agricultural goods and services. The NIFA's Agricultural Water Security Initiative offers a comprehensive opportunity to fund research, education, and extension projects in support of these needed changes in agricultural water management. Focusing this effort on holistic solutions that look across multiple sectors (agricultural, energy, environment, domestic etc.) will improve the likelihood of achieving sustainable solutions to complex water management issues.

\section{Literature Cited}

Barber, N.L. 2009. Summary of estimated water use in the United States in 2005: U.S. Geological Survey Fact Sheet 2009-3098.

Climate Change Science Program. 2008. The effects of climate change on agriculture, land resources, water resources, and biodiversity in the United States. A Report by the U.S. Climate Change Science Program and the Subcommittee on Global Change Research. Backlund, P., A. Janetos, D. Schimel, J. Hatfield, K. Boote, P. Fay, L. Hahn, C. Izaurralde, B.A. Kimball, T. Mader, J. Morgan, D. Ort, W. Polley, A. Thomson, D. Wolfe, M.G. Ryan, S.R. Archer, R. Birdsey, C. Dahm, L. Heath, J. Hicke, D. Hollinger, T. Huxman, G. Okin, R. Oren, J. Randerson, W. Schlesinger, D. Lettenmaier, D. Major, L. Poff, S. Running, L. Hansen, D. Inouye, B.P. Kelly, L. Meyerson, B. Peterson, and R. Shaw. U.S. Department of Agriculture, Washington, DC.

Council for Agricultural Science and Technology. 2009. Water, people, and the future: Water availability for agriculture in the United States. Issue Paper 44. CAST, Ames, IA.

Dobrowolski, J., M. O'Neill, L. Duriancik, and J. Throwe (eds.). 2008. Opportunities and challenges in agricultural water reuse: Final report. USDA-CSREES.

Dobrowolski, J.P. and M.P. O’Neill (eds.). 2005. Agricultural water security listening session final report. USDA REE, Washington, DC.

Intergovernmental Panel on Climate Change. 2001. Climate change 2001: The scientific basis. Contribution of Working Group I to the Third Assessment Report of the Intergovernmental Panel on Climate Change. [Houghton, J.T., Y. Ding, D.J Griggs, M. Noguer, P.J. van der Linden, X. Dai, K. Maskell, and C.A. Johnson (eds.)]. Cambridge University Press, Cambridge, UK, and New York, NY.

Intergovernmental Panel on Climate Change. 2007. Climate change 2007: Synthesis report. Contribution of Working Groups I, II and III to the Fourth Assessment Report of the Intergovernmental Panel on Climate Change [Core Writing Team, Pachauri, R.K. and A. Reisinger (eds.)]. IPCC, Geneva, Switzerland.

Karl, T.R., J.M. Melillo, and T.C. Peterson. (eds.). 2009. Global climate change impacts in the
United States. Cambridge University Press, Cambridge, UK.

Kenny, J.F., N.L. Barber, S.S. Hutson, K.S. Linsey, J.K. Lovelace, and M.A. Maupin. 2009. Estimated use of water in the United States in 2005: U.S. Geological Survey Circular 1344.

Knutson, C. 2008. The role of water conservation in drought planning. J. Soil Water Conserv. 63: 154A-160A.

Liang, X.-Z., K.E. Kunkel, G.A. Meehl, R.G. Jones, and J.X.L. Wang. 2008. Regional climate models downscaling analysis of general circulation models present climate biases propagation into future change projections. Geophys. Res. Lett. 35:L08709.

Lins, H.F., R.M. Hirsch, and J. Kiang. 2010. WaterThe Nation's fundamental climate issue: A White Paper on the U.S. Geological Survey Role and Capabilities, Circular 1347. Washington, DC.

Milly, P.C.D., J. Betancourt, M. Falkenmark, R.M. Hirsch, Z.W. Kundzewicz, D.P. Lettenmaier, and R.J. Stouffer. 2008. Stationarity is dead: Whiter water management? Science 319:573-574.

National Research Council. 2001. Envisioning the agenda for water resources research in the twenty-first century. The National Academies Press, Washington, DC.

National Research Council. 2004. Confronting the nation's water problems: The role of research The National Academies Press, Washington, DC.

National Science and Technology Council Committee on Environment and Natural Resources Subcommittee on Water Availability and Quality. 2007. A strategy for Federal science and technology to support water availability and quality in the United States, Report of NSTC CENR SWAQ.

U.S. Department of Agriculture. 2005. MyPyramid, Center for Nutrition Policy and Promotion, CNPP- 15.

Vorosmarty, C.J., P. Green, J. Salisbury, and R.B. Lammers. 2000. Global water resources: Vulnerability from climate change and population growth. Science 289:284-288.

Vorosmarty, C.J., P.B. McIntyre, M.O. Gessner, D. Dudgeon, A. Prusevich, P. Green, S. Glidden, S.E. Bunn, C.A. Sullivan, C. Reidy Liermann, and P.M. Davies. 2010. Global threats to human water security and river biodiversity. Nature 467:555-561.

Wiebe, K. 2003. Linking land quality, agricultural productivity, and food security. Resource Economics Division, Economic Research Service, U.S. Department of Agriculture. Agricultural Economic Report No. 823.

Wilby, R.L. and T.M.L. Wigley. 1997. Downscaling general circulation model output: A review of methods and limitations. Prog. Phys. Geogr. 21:530-548. 